\title{
EFFECTIVENESS OF PHENOL BLOCK IN THE MANAGEMENT OF SPASTICITY IN HEMIPLEGIA- A NON- RANDOMISED CONTROLLED TRIAL
}

\author{
Taha Peya ${ }^{1}$, Yumnam Ningthemba Singh², Naorem Bimol33, Tamphaleima Khuraijam4, Nandabir Singh ${ }^{5}$, Akoijam Joy Singh 6 \\ ${ }^{1}$ Ex-Postgraduate Trainee, Department of Physical Medicine and Rehabilitation, Regional Institute of Medical Sciences, Imphal, \\ Manipur. \\ ${ }^{2}$ Senior Registrar, Department of Physical Medicine and Rehabilitation, Regional Institute of Medical Sciences, Imphal, Manipur. \\ ${ }^{3}$ Assistant Professor, Department of Physical Medicine and Rehabilitation, Regional Institute of Medical Sciences, Imphal, Manipur. \\ ${ }^{4}$ Ex-Postgraduate Trainee, Department of Physical Medicine and Rehabilitation, Regional Institute of Medical Sciences, Imphal, \\ Manipur. \\ 5Professor, Department of Physical Medicine and Rehabilitation, Regional Institute of Medical Sciences, Imphal, Manipur. \\ ${ }^{6}$ Professor, Department of Physical Medicine and Rehabilitation, Regional Institute of Medical Sciences, Imphal, Manipur.
}

\section{ABSTRACT}

\section{BACKGROUND}

Peripheral nerve blocks have been shown to be an effective way of reducing spasticity. Phenol above $3 \%$ causes protein denaturation and axonal degeneration. Alcohol also causes tissue destruction such as nerve coagulation and muscle necrosis by denaturing proteins. Both are used in the management of gastroc-soleus spasticity, mainly by blocking the nerve supply to the gastrocnemius muscle.

The objectives of the study was to determine the effectiveness of $3 \%$ phenol block of the motor branches of posterior tibial nerve to the gastrocnemius muscles in the management of gastroc-soleus spasticity in hemiplegic patients.

\section{MATERIALS AND METHODS}

All hemiplegic patients aged 35 to 65 years with spasticity of gastroc-soleus grade 3 attending Physical Medicine and Rehabilitation, Regional Institute of Medical Sciences, Imphal were included in the study. Motor branches of the posterior tibial nerve to the gastrocnemius muscles were blocked with injection 3\% phenol in the intervention group and 50\% alcohol in control groups respectively. The spasticity was measured by using Modified Ashworth Scale (MAS) score. Followup was done at 1, 3 and 6 months. The data was analysed by using IBM SPSS Statistics for Windows, Version 21.0, Armonk, NY. Chi-square test, MannWhitney U test and Friedman's test were used to test for significance with p-value $<0.05$ taken as significant.

Study Design- Non-Randomised controlled trial.

Study Setting- Department of Physical Medicine and Rehabilitation, Regional Institute of Medical Sciences, Imphal.

\section{RESULTS}

At the end of first, follow-up grade 3 spasticity was seen only in $2.8 \%$ in the intervention group and $8.6 \%$ in the control group. In the $2^{\text {nd }}$ follow-up there was no case of grade 3 spasticity in the intervention group, but was seen only in $2.8 \%$ in the control group. In the $3^{\text {rd }}$ follow-up, proportion of patients with spasticity grade 3 was increased to $40 \%$ in the control group. However, there were no cases in the study group.

\section{CONCLUSION}

Alcohol and phenol block of gastrocnemius muscles in hemiplegic patients for the management of gastrocnemius spasticity was found to be effective, but long-lasting effects were found more in the phenol block.

\section{KEYWORDS}

Gastroc-Soleus Spasticity, Alcohol Block, Modified Ashworth Scale, Phenol Block.

HOW TO CITE THIS ARTICLE: Peya T, Singh YN, Bimol N, et al. Effectiveness of phenol block in the management of spasticity in hemiplegia- a non-randomised controlled trial. J. Evolution Med. Dent. Sci. 2017;6(94):6905-6908, DOI: $10.14260 /$ jemds/2017/1496

\section{BACKGROUND}

Stroke is one of the leading causes of mortality and morbidity. WHO clinically defines stroke as "rapid development of clinical signs and symptoms of focal neurological deficits lasting more than 24 hours or death with no apparent cause other than vascular origin." It can be broadly divided as ischaemic (85\%) and haemorrhagic (15\%). ${ }^{1}$

'Financial or Other Competing Interest': None.

Submission 31-10-2017, Peer Review 24-11-2017,

Acceptance 01-12-2017, Published 18-12-2017.

Corresponding Author:

Dr. Naorem Bimol,

Assistant Professor

Department of Physical Medicine and Rehabilitation,

Regional Institute of Medical Sciences, Imphal.

E-mail: bimoldr@yahoo.com

DOI: $10.14260 /$ jemds $/ 2017 / 1496$
The most significant physical impact on stroke survivors is long-term disability. Patients with hemiplegia also often develop abnormal patterns of muscle activity in the paretic limbs in the weeks after stroke with overactivity of muscles primarily affecting anti-gravity muscles in the lower limb. ${ }^{2}$

Spasticity is a motor disorder characterised by a velocity dependent increase in tonic stretch reflexes (muscle tone) with exaggerated tendon jerks resulting from hyperexcitability of the stretch reflex as one component of the upper motor neuron syndrome. ${ }^{3}$ In the lower limbs, adduction and extension of the knee with equinovarus foot is the most observed pattern. Gastroc-soleus spasticity is a significant functional problem in patients with stroke, because the condition often causes difficulty in standing and walking. ${ }^{4}$ Peripheral nerve blocks have been shown to be an 
effective way of reducing spasticity by interrupting the stretch reflex arc. ${ }^{5}$

Phenol acts as a local anaesthetic at low concentration $(<2 \%)$. At concentrations higher than $3 \%$, it causes protein denaturation and axonal degeneration with inflammation of the nervous tissue, which leads to neural destruction. Injection also causes occlusion and fibrosis in microcirculation around the nerve. 6

Alcohol also causes tissue destruction such as nerve coagulation and muscle necrosis by denaturing proteins, but its effects changes with concentration. At low concentrations $(5 \%-10 \%)$, it blocks sodium and potassium channels and acts as a local anaesthetic. When 35\% alcohol was applied onto nerves in animals, demyelination mostly in small fibres was seen with no axonal damage. And with 50\% - 100\% concentration, it causes paralysis with producing neuronal Wallerian degeneration and fibrosis. 7,8

Many studies have been conducted regarding tibial nerve branches motor point block to gastrocnemius by using neuromuscular stimulator with conflicting results. But there are only a few studies regarding alcohol and phenol block of peripheral nerves by using only surface anatomical landmark (blind technique) in the country. So this study was conducted to compare the effectiveness of alcohol and phenol block of motor nerve branches to gastrocnemius muscles in the management of gastroc-soleus spasticity.

Stroke is one of the leading causes of mortality and morbidity. WHO clinically defines stroke as "rapid development of clinical signs and symptoms of focal neurological deficits lasting more than 24 hours or death with no apparent cause other than vascular origin." It can be broadly divided as ischaemic (85\%) and haemorrhagic $(15 \%){ }^{1}$

The most significant physical impact on stroke survivors is long-term disability. Patients with hemiplegia also often develop abnormal patterns of muscle activity in the paretic limbs in the weeks after stroke with overactivity of muscles, primarily affecting anti-gravity muscles in the lower limb. ${ }^{2}$

Spasticity is a motor disorder characterised by a velocity dependent increase in tonic stretch reflexes (muscle tone) with exaggerated tendon jerks resulting from hyperexcitability of the stretch reflex, as one component of the upper motor neuron syndrome. ${ }^{3}$ In the lower limbs, adduction and extension of the knee with equinovarus foot is the most observed pattern. Gastroc-soleus spasticity is a significant functional problem in patients with stroke, because the condition often causes difficulty in standing and walking. ${ }^{4}$ Peripheral nerve blocks have been shown to be an effective way of reducing spasticity by interrupting the stretch reflex arc. 5

Phenol acts as a local anaesthetic at low concentration $(<2 \%)$. At concentrations higher than $3 \%$, it causes protein denaturation and axonal degeneration with inflammation of the nervous tissue, which leads to neural destruction. Injection also causes occlusion and fibrosis in microcirculation around the nerve. ${ }^{6}$

Alcohol also causes tissue destruction such as nerve coagulation and muscle necrosis by denaturing proteins, but its effects changes with concentration. At low concentrations (5\% - 10\%) it blocks sodium and potassium channels and act as local anaesthetics. When $35 \%$ alcohol was applied onto nerves in animals, demyelination mostly in small fibres was seen with no axonal damage. And with 50\% - 100\% concentration, it causes paralysis with producing neuronal Wallerian degeneration and fibrosis. 7,8

Many studies have been conducted regarding tibial nerve branches motor point block to gastrocnemius by using neuromuscular stimulator with conflicting results. But there are only a few studies regarding alcohol and phenol block of peripheral nerves by using only surface anatomical landmark (blind technique) in the country. So this study was conducted to compare the effectiveness of alcohol and phenol block of motor nerve branches to gastrocnemius muscles in the management of gastroc-soleus spasticity.

\section{MATERIALS AND METHODS}

The non-randomised controlled trial was conducted in the Department of Physical Medicine and Rehabilitation, Regional Institute of Medical Sciences, Imphal during September 2014 to August 2016. A pretested proforma was used to collect the detailed history of the patient including background characteristics, examination findings at baseline and subsequent follow-ups. All the hemiplegic patients aged between 35 - 65 years with gastroc-soleus spasticity attending the Department of PMR, RIMS, Imphal during the study period was included in the study. Cases with stroke within 3 - 12 months, spasticity of gastroc-soleus grade 3 were included in the study. Cases with recurrent stroke, foot deformity, spasticity grade 4 and less than grade 3, taking anti-spastic drugs, history of allergic reactions to alcohol and phenol, history of previous surgeries or injections and those who were not willing to participate were excluded from the study. Sample size was calculated by taking effect size as 0.5 , standard deviation of MAS score as 0.7 , significance level of $5 \%$ and power of $80 \%$. Adding $10 \%$ for loss for follow-up, the final calculated sample size was 70 (35 in each group). The participants were assigned to the treatment groups (intervention and control groups) by using haphazard allocation by alternation. In the intervention group nerve block was done using 3\% phenol and in the control group $50 \%$ alcohol was given. In both the cases neurodevelopmental exercises along with Tendo-Achilles stretching exercises were given. The severity of spasticity in the study groups was assessed by using Modified Ashworth Scale (MAS) score.12

The patient was made to lie in prone position with both feet hanging at the edge of the couch. Two points were marked on the medial and lateral mass of the calf muscle about four fingers breadth from the popliteal crease. ${ }^{9}$ Then after strict antiseptic and aseptic precautions, $2 \mathrm{~mL}$ of $2 \%$ lignocaine was given over the marked areas and after about 5 mins any reduction of spasticity and clonus were checked Then injection $3 \%$ phenol and $50 \%$ alcohol was given in the intervention and control groups respectively. Spasticity was then assessed by Modified Ashworth Scale (MAS) ${ }^{10}$ after 1, 3 and 6 months.

The data so collected was analysed by using SPSS version 21 and descriptive statistics like percentages, mean and standard deviations was used. Chi-square test and Friedman's test was used to test for significance. A P-value of $<0.05$ was taken as significant. Ethical approval was obtained from the Institutional Ethics Committee, RIMS, Imphal. 


\section{RESULTS}

A total of 70 hemiplegic patients with gastroc-soleus spasticity grade 3 who fulfilled the inclusion criteria were included in the study. The majority of the patients were within the age group of $54-65$ years. Males represent about $70 \%$ of the cases.

Table 1 showed that there was no significant difference between the intervention and control groups at baseline. Majority of cases were infarcts (62.9\%) and right side was involved more than the left side (60.0\%) among the intervention group as compared to the controls (54.3\%).

Table 2 showed that the proportion of cases with spasticity grade 2 and 3 were significantly more among the control group as compared to the intervention group (85.7\% vs $65.7 \%)$, ( $8.6 \%$ vs $2.8 \%$ ) at the end of first followup.

Table 3 showed that at the end of second follow-up $97.2 \%$ of cases in the control group had grade 1 spasticity, while in the intervention group only 19 (54.3\%) had grade 1 spasticity. $16(45.7 \%)$ cases had grade 2 spasticity in the intervention group, while none of the cases in the control group had grade 2 spasticity. This finding was found to be statistically significant.

Table 4 showed that proportion of cases with grade 3 spasticity increased to $40 \%$ in the control group, whereas in intervention group none of the cases had grade 3 spasticity and the finding was statistically significant.

Table 5 showed that the mean MAS scores at baseline and at subsequent follow-ups within both control and study groups differed significantly. The mean MAS score reduced to significantly lower levels in both studies and control groups. However, it was observed that the mean MAS score in the control group increased from second followup.

\begin{tabular}{|c|c|c|c|c|}
\hline Characteristics & $\begin{array}{c}\text { Control } \\
\text { Group } \\
\text { N (\%) }\end{array}$ & $\begin{array}{c}\text { Intervention } \\
\text { Group } \\
\text { N (\%) }\end{array}$ & $\begin{array}{c}\text { Total } \\
\text { N (\%) }\end{array}$ & $\begin{array}{c}\text { P- } \\
\text { value }\end{array}$ \\
\hline Age in Years & \multicolumn{5}{|c|}{} \\
\hline $35-44$ & $9(25.7)$ & $5(14.3)$ & $14(20.0)$ & \\
$45-54$ & $12(34.3)$ & $15(42.9)$ & $27(38.6)$ & 0.47 \\
$55-65$ & $14(40.0)$ & $15(42.9)$ & $29(41.4)$ & \\
\hline Sex & \multicolumn{5}{|c|}{} \\
\hline Male & $22(62.9)$ & $27(77.1)$ & $49(70.0)$ & 0.19 \\
Female & $13(37.1)$ & $8(22.9)$ & $21(30.0)$ & \\
\hline Type of Stroke & \multicolumn{5}{|c|}{} \\
\hline Infarct & $19(54.3)$ & $22(62.9)$ & $41(58.6)$ & \\
Haemorrhage & $16(45.7)$ & $13(37.3)$ & $29(41.4)$ & 0.467 \\
\hline $\begin{array}{c}\text { Duration of } \\
\text { Stroke }\end{array}$ & \multicolumn{5}{|c|}{} \\
\hline $\begin{array}{c}\text { 3 - 6 months } \\
>\text { 6 months }\end{array}$ & $16(45.7)$ & $26(74.3)$ & $42(60.0)$ & \\
\hline Side of & $19(54.3)$ & $9(25.7)$ & $28(40.0)$ & 0.015 \\
Hemiplegia & \multicolumn{5}{|c|}{} \\
\hline Right & $19(54.3)$ & $21(60.0)$ & $40(57.1)$ & \\
Left & $16(45.7)$ & $14(40.0)$ & $30(42.9)$ & 0.809 \\
\hline
\end{tabular}

Table 1. Baseline Characteristics of the Study Population

\begin{tabular}{|c|c|c|c|}
\hline $\begin{array}{c}\text { Spasticity } \\
\text { Grade }\end{array}$ & $\begin{array}{c}\text { Control Group } \\
\text { N (\%) }\end{array}$ & $\begin{array}{c}\text { Intervention } \\
\text { Group N (\%) }\end{array}$ & P-value \\
\hline Grade 1 & $2(5.7)$ & $11(31.4)$ & \\
\hline Grade 2 & $30(85.7)$ & $23(65.7)$ & 0.017 \\
\hline Grade 3 & $3(8.6)$ & $1(2.8)$ & \\
\hline \multicolumn{4}{|c|}{ Table 2. Spasticity Grade of Gastrocnemius Muscle at 1st } \\
Followup in the Study Groups \\
\hline
\end{tabular}

\begin{tabular}{|c|c|c|c|}
\hline $\begin{array}{c}\text { Spasticity } \\
\text { Grade }\end{array}$ & $\begin{array}{c}\text { Control Group } \\
\text { N (\%) }\end{array}$ & $\begin{array}{c}\text { Intervention } \\
\text { Group N (\%) }\end{array}$ & P-value \\
\hline Grade 1 & $34(97.2)$ & $19(54.3)$ & \\
\hline Grade 2 & $0(00.0)$ & $16(45.7)$ & 0.000 \\
\hline Grade 3 & $1(2.8)$ & $0(00.0)$ & \\
\hline \multicolumn{3}{|c|}{ Table 3. Spasticity Grade of Gastrocnemius Muscle } \\
at 2nd Followup in the Study Groups \\
\hline
\end{tabular}

\begin{tabular}{|c|c|c|c|}
\hline $\begin{array}{c}\text { Spasticity } \\
\text { Grade }\end{array}$ & $\begin{array}{c}\text { Control } \\
\text { Group } \\
\text { N (\%) }\end{array}$ & $\begin{array}{c}\text { Intervention } \\
\text { Group } \\
\text { N (\%) }\end{array}$ & P-value \\
\hline Grade 1 & $21(60.0)$ & $32(91.4)$ & \\
\hline Grade 2 & $0(00.0)$ & $3(8.6)$ & 0.017 \\
\hline Grade 3 & $14(40.0)$ & $0(00.0)$ & \\
\hline \multicolumn{3}{|c|}{ Table 4. Spasticity Grade of Gastrocnemius Muscle } \\
at 3rd Followup in the Study Groups \\
\hline
\end{tabular}

\begin{tabular}{|c|c|c|c|c|c|}
\hline $\begin{array}{c}\text { Control } \\
\text { Group } \\
\text { Mean MAS } \\
\text { Score (SD) }\end{array}$ & Baseline & $\begin{array}{c}\text { At 1 } \\
\text { Month }\end{array}$ & $\begin{array}{c}\text { At 3 } \\
\text { Months }\end{array}$ & $\begin{array}{c}\text { At 6 } \\
\text { Months }\end{array}$ & P-value* \\
\cline { 2 - 6 } & $3.0(0.1)$ & $1.7(0.5)$ & $1.6(0.9)$ & $1.7(0.9)$ & 0.000 \\
\hline $\begin{array}{c}\text { Intervention } \\
\text { Group } \\
\text { Mean MAS } \\
\text { Score (SD) }\end{array}$ & $3.0(0.1)$ & $2.02(0.3)$ & $1.4(0.5)$ & $1.0(0.2)$ & 0.000 \\
\hline \multicolumn{7}{|c|}{ Table 5. Within Group Comparison of Mean MAS } \\
Score in the Study Groups \\
\hline \multicolumn{7}{|c|}{} \\
\hline
\end{tabular}

${ }^{*} \mathrm{P}$-value for Friedman's Test

\section{DISCUSSION}

In this study, 70 patients with gastrocnemius spasticity of grade 3 were recruited. They were randomised into two groups, intervention and control. For the intervention group $3 \%$ phenol and for the control group 50\% alcohol were used. All the cases were treated with routine neurodevelopment exercises based on Bobath's technique. The reduction of gastrocnemius spasticity was measured by Modified Ashworth scale and follow-up was done at 1, 3 and 6 months.

Phenol neurolysis of peripheral nerves for spasticity has been well described in the literature as a neurolytic agent for the past 30 years. ${ }^{1}$ In a long-term follow-up study of phenol block of the tibial nerve by Petrillo et al, 92 tibial nerve blocks with phenol were performed in 59 patients for treatment of severe spasticity of foot and it was observed that the Achilles tendon reflexes was abolished, ankle clonus eliminated and resistance to passive stretch was reduced following the procedure in all patients. ${ }^{11}$ In this study, phenol (3\%) block was given to both medial and lateral heads of gastrocnemius and there was reduction in spasticity to grade 1 in $91.4 \%$ and grade 2 in $8.6 \%$ at 6 months follow-up in the intervention group. In the control group, only $60 \%$ of cases were in grade 1 and $40 \%$ had grade 3 spasticity in control group. This means that the effect of phenol lasts longer than that of alcohol, even though both alcohol and phenol may cause protein denaturation and axonal degeneration. At 3 months improvement was dramatic in control group, that $97.1 \%$ of the patients had grade 1 spasticity. It may be due to neurolytic action of the alcohol with addition of neurodevelopment exercises based on Bobath technique. Spasticity was reduced to grade 1 in $91.4 \%$ of cases in the intervention group at 6 months follow-up, thereby demonstrating long lasting effects of phenol. 
This finding was almost similar to a study conducted by Kocabas et al, where the spasticity score for the ankle plantar flexor was reduced in all 10 patients immediately after motor branch block and it was maintained over the 6 months follow-up period in 7 patients. 12 Moore TJ et al in their study evaluated the use of open phenol blocks to the motor branches of the tibial nerve in adult-acquired spasticity in nine patients (six head injury and three spinal cord injury) and found that spasticity was decreased in all patients who underwent phenol injections into the motor branches of the tibial nerve and 5 patients $(55.5 \%)$ were able to ambulate subsequently, which suggests that phenol injection to the motor branches of the tibial nerve safely and effectively prevents foot and ankle contractures following head or spinal cord injuries. ${ }^{13}$

Pelisser $\mathrm{J}$ and his team studied the chemical neurolysis using alcohol in the treatment of spasticity in hemiplegic patients and found that neurolysis with alcohol injection in the nerve trunk or at the motor point destroys the gamma fibres and reduces spasticity without impairing motor command. ${ }^{14}$

\section{CONCLUSION}

From this study, we conclude that alcohol and phenol block of gastrocnemius muscles for the management of gastroc-soleus spasticity in hemiplegic patients were found to be effective. The effect of phenol lasts longer than that of alcohol. The treatment with alcohol and phenol are cheap as compared to other methods like injection of botulinum toxin. However, suitable preparation and proper storage of phenol are required.

\section{REFERENCES}

[1] Stroke-1989. Recommendations on stroke prevention, diagnosis and therapy. Report of the WHO task force on stroke and other cerebrovascular disorders. Stroke 1989;20(10):1407-31.

[2] Eliot JE, Harvey LR. Rehabilitation of stroke syndromes. In: Bradom LR, (eds). Handbook of physical medicine and rehabilitation. $2^{\text {nd }}$ edn. New York: WB Saunders, 2004:727-56.
[3] Lance J. Spasticity: disorders motor control. In: Feldman RG, Young RP, Koella WP, (eds). Symposium synopsis. Miami, FL: Year Book Medical Publishers, 1980:485-94

[4] Khalili AA, Betts HB. Peripheral nerve block with phenol in the management of spasticity. Indications and complications. JAMA 1967;200(13):1155-7.

[5] Sindou M, Mertens P. Selective neurotomy of the tibial nerve for treatment of spastic foot. Neurosurgery 1988;23(6):738-44.

[6] Botte MJ, Abrams RA, Bodine-Fowler SC. Treatment of acquired muscle spasticity using phenol peripheral nerve blocks. Orthopaedics 1995;18(2):151-9.

[7] Gracies JM, Elovic E, McGuire J, et al. Traditional pharmacological treatment for spasticity. Part I: local treatments. Muscle Nerve Suppl 1997;6:S61-91.

[8] Kong KH, Chua KSG. Neurolysis of the musculocutaneous nerve with alcohol to treat post stroke flexor spasticity. Arch Phys Med Rehabil 1999;80(10):1234-6.

[9] Mishra UK, Kalita J. Technique of electromyography. In clinical neurophysiology. Mishra UK, Kalita J. (eds). $1^{\text {st }}$ edn. New Delhi, B.I. Churchil Livingstone Pvt. Ltd, 1999:pp 143.

[10] Bohannon RW, Smith MB. Interrater reliability of a modified Ashworth scale of muscle spasticity. Phys Ther 1987;67(2):206-7.

[11] Petrillo CR, Knoploch S. Phenol block of the tibial nerve for spasticity: a long term follow-up study. Int Disabil Stud 1988;10(3):97-100.

[12] Kocabas H, Salli A, Demir AH, et al. Comparision of phenol and alcohol neurolysis of tibial nerve motor branches to the gastrocnemius muscle for treatment of spastic foot after stroke: a randomized controlled pilot study. Eur J Phys Rehabil Med 2010;46(1):5-10.

[13] Moore TJ, Anderson RB. The use of open phenol blocks to the motor branches of the tibial nerve in adult acquired spasticity. Foot Ankle 1991;11(4):219-21.

[14] Pelissier J, Viel E, Enjalbert $M$, et al. Chemical neurolysis using alcohol in the treatment of spasticity in the hemiplegia. Can Anaesthesiol 1993;41(2):13943. 